\title{
Management of Education Services for Children
}

\section{Istaryatiningtias $^{1 *}$, Daliman ${ }^{2}$}

${ }^{1}$ Muhammadiyah University of Prof. DR. HAMKA, Indonesia

${ }^{2}$ SLB Negeri 3 Jakarta

A R T I C L E I N F O

Article history:

Received 28 December

2020

Received in revised

Form 28 January 2020

Accepted 01 February

2021

Available online 04

February 2021

Keywords:

Managemen Education

Services, deaf children

\begin{abstract}
A B S T R A C T
This research was motivated by the fact that the quality of management education services for deaf children has not been fulfilled. This research is important to do to determine the quality of education service management for children with hearing impairment. The research method used by researchers is descriptive qualitative research. In this study the authors found the results of their research; (1) Old buildings that cost money. (2) Teacher competition in controlling the Maternal Reflective Method (MMR) is caused by weak knowledge, skills and abilities in providing educational services to children with hearing impairment. (3) The condition of speech building teachers and voice and rhythm perception communication coaches (PKPBI) is less skilled in quality and quantity, and there are still many teachers who are retired and transferred. The conclusion of this research can be seen that the planning, organizing, movement, supervision and service have been implemented properly.
\end{abstract}

\section{Introduction}

Education is one of the human rights without exception. Every child has the right to receive educational qualifications including students with special needs. In Indonesia, students with special needs can go to school regularly in a legal and formal inclusive school environment in accordance with Article 31 of the law, and in accordance with the special provisions of Permendiknas 2009 No. 70. The speech and language ability of hearing impaired students will also improve when placed in a language-rich environment (Jesslin \& Kurniawati, 2020). Milla's findings also show the impact of inclusive education on the social skills and self-esteem of students with special needs. With the improvement of skills and deep self-esteem with special needs, students will have the ability to develop their potential (Milla, 2018; Taruvinga Mushoriwa, 2001). Children with disabilities, even when assigned to classrooms, remain socially and academically excluded in many countries. Regarding the success of school practices with special needs, (Bergsma, 2000) notes the importance of the attitudes of principals, teachers, and parents. It can be said that teachers are the main implementers of special education. Likewise, (Parey, 2019; Sosu et al., 2010;) shared the view that in classroom practice children with disabilities are influenced by teacher attitudes. Therefore, inclusive education policies and programs depend on the attitudes of teachers

Around the world, education policymakers are demanding more schools for children with special needs where teachers address educational needs of all students (OECD, 2010). In addition, the government is obliged to develop education system to ensure that all children receive education even if children with disabilities (UNESCO, 1994). However, some inclusive education systems are only viewed as education for children with disabilities. Through schools with special needs, children with disabilities must also be able accommodated in the education system. (Taruvinga Mushoriwa, 2001) highlights that children persons with disabilities, even when assigned to classrooms, remain socially and academically excluded in many countries. Associated with the successful practice of schools with special needs, (Bergsma, 2000) notes the importance of the attitudes of principals, teachers, and parents. It can be said that, teachers are the main implementers of special education. Likewise, (Donohue \& Bornman, 2015; Parey, 2019; Sosu et al., 2010; Taruvinga Mushoriwa, 2001) share the view that classrooms the practice of children with disabilities is influenced by the attitude of the teacher. Therefore, inclusive education policies and programs depend about the teacher's attitude

The sense of hearing is a window of someone's information. Various information about events that occur from various parts of the world can be obtained through listening / listening activities. In 
addition, through the sense of hearing someone is also in touch with the environment. Deafness occurs in the sense of hearing. Because the sense of hearing cannot be utilized optimally, children who are deaf (deaf children) find it difficult to develop independent language skills. Therefore, the most severe impact felt by children with hearing impairment is poverty in language. They are less or unable to speak and understand reading because of their limited vocabulary and lack of understanding of language structures so that they cannot convey and capture messages, both orally and in writing according to reliable Indonesian rules.

Most of the students are deaf with indicates below average educational attainment in subjects such as mathematics or reading and writing. Several studies have also reported that children with hearing loss have a higher frequency of failure, with between $25 \%$ and $53 \%$ in school (Eckl-Dorna et al., 2004; Venail et al., 2010). Apart from that, for the most part children need translators at school to help them understand their teacher (Diaz et al., 2019; Sorkin \& Zwolan, 2004). Most students and adults with hearing impairments have limitations in communicating and participate fully in general public activities (Deus, 2013). There are several communication options that can be used by someone who is suffering, one of which involves the use of sign and written language (more visual-based communication), the use of verbal or spoken language (using hearing aids), and / or use both to communicate, remembering contexts, situations, and special needs of individuals (Vermandel et al., 2008). This need can be felt not only in the school environment but also in the family environment: only about $10 \%$ deaf children are born to parents who are also deaf (Marschark et al., 2011). Therefore, barriers to communication can occur in the family sphere when parents feel unprepared to handle the special needs of their newborn with an unexpected (deaf) situation and when there is no language proficiency of the same between parent and child (Hintermair, 2006; Marschark, M., Lang, H., \& Albertini, 2001; Zaidman-Zait, 2007). The same can be the case for teachers and professionals who work with deaf students and their families. Be aware of the strengths and weaknesses of students and families, and about what is their primary need on a regular basis, very important for the success of education, intervention and increase in students over the years (Capitão et al., 2012). Schools must develop and implement policies that promote parental involvement, so that there is and effective communication and sharing between family and school, and parents can be empowered and enabled to advocate for their child throughout life (Swanwick, 2010).

To overcome poverty for deaf children, teachers at Special School for the Deaf (SLB-B), especially in the Special Kindergarten and Special Elementary School education units are expected to provide language input and develop language skills for deaf children. so that they reach the level of mastery of the actual language (post-language) where they can use and apply appropriately the rules of language that apply in their environment independently.

Referring to the concept of sensory deprivation proposed by Myklebust in Marc Marchark, it is argued that the malfunction of one of the senses will cause distortion in the acquisition of information and one's perception. Due to the overall reduction in the material resources of the organism necessary for the development of the mind, there is an imbalance of psychological processes in general which results in a different form of experience, the natural base of perception, conception, cognition, imagination, and thought turning into a configuration new things that occur naturally and unconsciously (Marschark, 1994). The heaviest impact of deafness is the inhibition of speech and language development which results in poverty in language, as stated by Helen Keller in Reed as follows: The problems of defness are deeper and more complex, if not more important than those of blindness. Deafness is a musch worse misfortune. For it means the loss of the most vital stimulus-the sound of the voice that brings language, sets thought astir, and keeps us in the intellectual company of man (Reed, 1984).

Planning for educational services for children with hearing impairment is carried out after several treatments have been carried out, starting from detection and assessment related to hearing impairment. As previously stated, the heaviest impact of deafness is poverty in language because deaf children do not experience language input like hearing children in general. Therefore, in order for deaf children to have significant language development, they must immediately enter the world of education or early childhood education at special deaf educational institutions. If hearing children generally enter early childhood education at the age of 4 years, educational institutions for deaf children accept them at 2 years of age. This is done so that deaf children can immediately receive language input through various existing media. The important thing that is done in this special early education service is sensitivity in detecting and perceiving sounds that are around human life, especially the sounds of language. Therefore, pre-speech training, like babies in general, is carried out by educators so that deaf children get used to speaking and language conditions as the main capital of communication with their environment. Deaf schools that have early education services generally accept children from 2 to 6 years of age. Technically, this early education service planning contains programs so that children with hearing impairment can detect, differentiate, identify, and comprehend sounds and the formation of phonemes so that children can say 
simple words according to their age development. Therefore, the learning atmosphere is always colored by conversations about children's experiences.

Further education services are formal education services starting from the education units of the Special Deaf Primary School (SDLB-B), the Special Deaf Junior High School (SMPLB-B), and the Special Deaf Senior High School (SMALB-B). The service planning carried out by the teacher is in the form of a series of academic programs summarized in the annual program, semester program, learning syllanus, lesson plan (RPP) and special service programs to minimize obstacles caused by hearing impairment. From the aspect of education delivery, schools also have a teacher recruitment plan with certain criteria and a coaching plan to increase teacher professionalism in providing educational services for deaf children.

The author has conducted a preliminary study by making observations in several special schools in the DKI Jakarta area. From the preliminary study, it was found that the language skills of SDLB-B students were generally still at the pre-linguality level so that students could not express / pronounce what they felt and experienced even in the simplest language. They haven't been able to answer basic questions about themselves spontaneously, such as answering questions about name, age, address, parents or about school. However, of the 40 (forty) SDLB-B in the DKI Jakarta area visited in the preliminary study, the authors found two SDLB-B which had students with language mastery at the interlinguality and post-linguality levels. Students in both SDLB-B can express what they see, feel, and experience, so they can have simple conversations about daily activities or tell about themselves.

The gap in the language proficiency level of SDLB-B students indicates the quality of education service management. The management in question is the management of SLB-B as an educational institution that organizes and implements education for deaf students including planning, organizing, movement, and control. In the planning aspect, in general the SLB-B management lacks a program for recruitment, training and coaching of educators. Recruitment carried out by SLB-B is based on the need for the quantity of teaching staff, not on the quality and qualifications of the teaching staff. This is exacerbated by not carrying out an adequate training and guidance program so that there are still teachers who do not have comprehensive knowledge of hearing impairment. The limited knowledge of teachers about deafness has an impact on the limited education services, both for special deafness services and academic programs.

The results of simple interviews with SDLB-B educators in the preliminary studies that have been conducted, it can be concluded that tertiary institutions that produce special education educators (LPTK) contribute to the limited knowledge of teachers about hearing impairment. The LPTKs did not provide adequate knowledge about special program services for hearing impairment known as Sound and Rhythm Perception Communication Development (PKPBI) or specific methodologies on learning for deaf children. This results in teachers not mastering how to deliver deaf children to receive and perceive sounds, especially language sounds as a modality for language development and language activities (communication). In addition, teachers are also trapped in stiffness and deadlocked communication in the learning process because they do not master the learning method for deaf children known as the Maternal Reflective Method (MMR).

The implementation of PKPBI has an impact on assessment activities and the availability of special PKPBI spaces with the completeness of supporting facilities, while the implementation of MMR will have an impact on class arrangements and learning nuances which are colored by interactive between teachers and students, as well as students and students. The class arrangement in question is the arrangement of tables and chairs of students in the form of a circle or horseshoe to make it easier for students to capture speech in communication activities in processing and interpreting learning material. Adequate SLB-B governance as described above is an effort to improve the quality of education services for deaf students so as to optimize customer satisfaction (students and parents). This research is important to do to determine the quality of education service management for children with hearing impairment.

\section{Methods}

To obtain an in-depth picture of this research, researchers used a qualitative approach. This approach is quite an adequate choice, because the qualitative approach is a research procedure that produces descriptive data in the form of written and spoken words from people and observed behavior and is rooted in the natural background as wholeness. In line with this opinion, Moleong argues that qualitative research intends to understand the phenomena experienced by research subjects such as behavior, perception, or motivation for action holistically by means of descriptions in the form of words and language, in a special natural context by utilizing various natural sources (Moleong, 2008). Given that 
this study investigates phenomena in a real context by utilizing various sources of evidence, the research strategy used is a case study. Deddy Mulyana argues that case study research seeks to examine as much data as possible on the subject under study using various methods, such as interviews (curriculum vitae), observations, survey documents (results), and any data to describe a case in detail (Mulyasa, 2005).

A case study seen from the dimension of positivistic research can also be called a longitudinal study which is continuous for a relatively long period of time and follows an interactive process of various variables. Longitudinal studies are contrasted with cross-sectional studies which take time samples, behavior samples, and event samples at a particular time (Muhadjir, 2000). In connection with the discussion of this thesis, a longitudinal case study will provide a detailed description of the background, characteristics and characteristics of the case which are then drawn into a general conclusion regarding the problem of management of educational services for children with hearing impairment. will be observed in this study.

The case in this study is the school as a single case. The choice of school as a case is motivated by thinking because researchers will examine the phenomenon of deaf children's education service management in the current real-life context by utilizing various sources of comprehensive evidence from school components by involving foundation administrators as education providers, school principals and teachers as implementers of education, as well as other supporting factors in efforts to optimize educational services for deaf children. Other reasons for choosing a single case include, among other things, that a single case can: 1) present a significant contribution to the development of knowledge and theory, 2) present an extreme or unique case, and 3) represent the case itself when the researcher has the opportunity to observe and analyze a phenomenon.

\section{Result and Discussion}

\section{Result}

Further education services are formal education services starting from the education units of the Special Deaf Primary School (SDLB-B), the Special Deaf Junior High School (SMPLB-B), and the Special Deaf Senior High School (SMALB-B). The service planning carried out by the teacher is in the form of a series of academic programs summarized in the annual program, semester program, learning syllanus, lesson plan (RPP) and special service programs to minimize obstacles caused by hearing impairment. From the aspect of education delivery, schools also have a teacher recruitment plan with certain criteria and a coaching plan to increase teacher professionalism in providing educational services for deaf children.

The author has conducted a preliminary study by making observations in several special schools in the DKI Jakarta area. From the preliminary study, it was found that the language skills of SDLB-B students were generally still at the pre-linguality level so that students could not express / pronounce what they felt and experienced even in the simplest language. They haven't been able to answer basic questions about themselves spontaneously, such as answering questions about name, age, address, parents or about school. However, of the 40 (forty) SDLB-B in the DKI Jakarta area visited in the preliminary study, the authors found two SDLB-B which had students with language mastery at the interlinguality and post-linguality levels. Students in both SDLB-B can express what they see, feel, and experience, so they can have simple conversations about daily activities or tell about themselves.

The result of this research is (1) Carry out education service plan according to the ability and needs of each hearing-impaired person. (2) Organize all processes involved in the treatment of hearingimpaired children (psychologists, audiologists, educators). (3) Incentive performance is to motivate all educators and educators so that they can work best, wholeheartedly, and sincerely, and enjoy their work to achieve the set goals. (4) Regularly realize control in the form of supervision, performance and guidance. (5) The educational services provided to deaf-mute children must be accurate and best (reliable). The specific implementation should refer to the needs and abilities of each person, whether the building is in good condition, whether the school conditions are good, and there are enough parking spaces, Care and concern (empathy) are realized. In the form of emotion, it can provide services in good faith and handle education (responsibility) quickly and accurately, because it has enough educators and educators, so it is necessary to maintain the knowledge, abilities and skills of teachers. (6) To understand deaf children in depth, it is necessary to understand deaf children in terms of their characteristics, language and speech, intelligence, social and emotional development. 


\section{Discussion}

Technology has a very positive impact on children in the classroom. If the technology in the classroom is designed to be suitable for use by children with disabilities, it can have a great impact, and it can support the teaching process that is usually adapted to the needs of certain children. An example of the literacy teaching process for deaf children. The strategy must be different from the strategy used by hearing children. Storytelling is one of the strategies that have proven effective in the teaching process. Storytelling can affect all aspects of children's lives, such as the development of communication skills (Garzotto et al., 2010). In the field of education, storytelling has proven to be a resource for working in various fields of knowledge, such as natural sciences, foreign language teaching (Reyes Torres et al., 2012), sign language, programming (Burke \& Kafai, 2010) and literacy (Flórez-Aristizábal et al., 2019).

Teachers must have the skills as instructional designers, instructional managers and student learning assessors to achieve ideal learning practices. The learning that is most suitable for integrated courses must be tailored to the needs of normal students and students with special needs. The series of stages containing the learning process in the class are usually the same as the learning process in other regular classes (Khairuddin \& Miles, 2020).

Salary is a management method to improve employee performance, motivate and increase employee satisfaction (Aprijon, 2017). Several studies have investigated Teacher's compensation and its impact on performance. (María, 2018) found that although it has no significant impact on student performance, courses can increase teachers' salaries, and school investment can better change teachers' performance. (Castro \& Pacifico, 2018) show that the bonus plan for teachers can keep teachers continuing to teach in the school, thereby reducing the number of vacancies for new teachers, but has no impact on learning outcomes

The supervision of the principal is a series of efforts to improve teaching conditions, such as helping teachers to teach and helping students learn better. But in fact, in the eyes of the public, there are still many people who believe that the supervision of the principal is equivalent to the supervision of smell. Overall, supervision means working hard to help teachers so that teachers can help students learn better. Practical supervision is beneficial development theory should pay attention to teaching and more tactical tool leadership, and mention the need for tool development to achieve the specific goals of the supervisor (Suchyadi \& ., 2018).

A school that accommodates children with special needs is a special school (SLB). Special schools (SLB), as educational institutions, are prepared to provide special education services for certain disabled persons and provide them with special education services (Noviandari \& Huda, 2018). The function of the special school itself is only to provide teaching based on the ability of children with special needs, and the purpose is to provide a teaching system that is different from other ordinary children who only learn to read, write, work and count. Children with special needs receive special courses according to their needs to provide a teaching system different from other ordinary children who only learn to read, write, work and count, while children with special needs receive special courses according to their needs the study prepares them for their personal needs and special education.

To understand deaf children in depth, it is necessary to understand deaf children in terms of characteristics, language and speech, intelligence, social and emotional development. Deaf children are part of children with special needs who need special education to gradually build self-confidence, independence (not 100\% dependent on their environment) and have the skills to help themselves. Deaf children are also expected to be able to socialize with the environment in which they are located and optimize the competition they have.

\section{Conclusion}

Law No. 20 of 2003 on the national education system stipulates: "Special education is education for students in difficulties. Follow the learning process due to physical, emotional, mental and social obstacles. This provision is for children with special needs because it provides them with a solid foundation for opportunities just like other normal children education and agriculture. Because by using the remaining potential to have children, develop himself so that one day he can live Independent like ordinary people. To this end, teachers and parents need to understand the needs and potential of their children. Although their intelligence is no different from that of normal children, except for children with intellectual disabilities, due to the mismatch, the integrity of their abilities must be deep. Learning requires different facilities. In order not to burden the teacher, Children with special needs need to adapt to special school education or integration into classes. If there are only children or have the same type of disease, inclusive courses are more meaningful for children. 


\section{References}

Aprijon, A. (2014). Pengaruh Kompensasi terhadap Kinerja Guru Slta di Kecamatan Bangkinang. MENARA, 13(1), 88-101. http://ejournal.uin-suska.ac.id/index.php/Menara/article/view/844.

Bergsma, S. (2000). The regular classroom as battleground for inclusive special needs education: An assessment of options of special needs education in the Commonwealth Caribbean. Office of the UNESCO Representative in the Caribbean.

Burke, Q., \& Kafai, Y. B. (2010). Programming \& storytelling: Opportunities for learning about coding \& composition. Proceedings of IDC2010: The 9th International Conference on Interaction Design and Children, 348-351. https://doi.org/10.1145/1810543.1810611.

Capitão, S., Almeida, A. M. P., \& Vieira, R. M. (2012). Connecting families and schools of students with deafness: Describing the ICT and internet use in education. Procedia Computer Science, 14(Dsai), 163-172. https://doi.org/10.1016/j.procs.2012.10.019.

Castro, J., \& Esposito, B. (2018). The Effect of Bonuses on Teacher Behavior: A Story with Spillovers. Working paper 104, Peruvian Economic Association.

Deus, M. D. L. F. (2012). Surdez: Linguagem, Comunicação E Aprendizagem Do Aluno Com Surdez Na Sala De Aula Comum. Revista Anápolis, Seminário de Pesquisa em Educação da rede municipal de ensino de Anápolis: Desafios $\quad$ e $\quad$ Possibilidades, http://www.anapolis.go.gov.br/revistaanapolisdigital/wp-content/uploads/2013/05/Maria-deLourdes-Fonseca.pdf.

Diaz, L., Labrell, F., Le Normand, M. T., Guinchat, V., \& Dellatolas, G. (2019). School achievement of deaf children ten years after cochlear implantation. Neuropsychiatrie de l'Enfance et de l'Adolescence, 67(1), 50-57. https://doi.org/10.1016/j.neurenf.2018.07.006.

Donohue, D. K., \& Bornman, J. (2015). South African Teachers' Attitudes toward the Inclusion of Learners with Different Abilities in Mainstream Classrooms. International Journal of Disability, Development and Education, 62(1), 42-59. https://doi.org/10.1080/1034912X.2014.985638.

Eckl-Dorna, J., Baumgartner, W. D., Jappel, A., Hamzavi, J., \& Frei, K. (2004). Successful integration of cochlear-implanted children in regular school system. International Congress Series, 1273(C), 409412. https://doi.org/10.1016/j.ics.2004.08.101.

Flórez-Aristizábal, L., Cano, S., Collazos, C. A., Benavides, F., Moreira, F., \& Fardoun, H. M. (2019). Digital transformation to support literacy teaching to deaf Children: From storytelling to digital interactive storytelling. Telematics and Informatics, 38, 87-99. https://doi.org/10.1016/j.tele.2018.09.002.

Garzotto, F., Paolini, P., \& Sabiescu, A. (2010). Interactive storytelling for children. Proceedings of IDC2010: The 9th International Conference on Interaction Design and Children, 2(1), 356-359. https://doi.org/10.1145/1810543.1810613.

Hintermair, M. (2006). Parental resources, parental stress, and socioemotional development of deaf and hard of hearing children. Journal of Deaf Studies and Deaf Education, 11(4), 493-513. https://doi.org/10.1093/deafed/enl005.

Jesslin, J., \& Kurniawati, F. (2020). Perspektif Orangtua terhadap Anak Berkebutuhan Khusus di Sekolah Inklusif. JPI (Jurnal Pendidikan Inklusi), 3(2), 72. https://doi.org/10.26740/inklusi.v3n2.p72-91.

Khairuddin, K. F., \& Miles, S. (2020). School staff members' and parents' experiences of the inclusion of deaf children in Malaysian mainstream schools. Education 3-13, 48(3), 273-287. https: //doi.org/10.1080/03004279.2019.1664403.

Marschark, M., Lang, H. G., \& Albertini, J. A. (2001). Educating deaf students: From research to practice. Oxford University Press.

Marschark, M. (1994). Asal usul dan Interaksi dalam Perkembangan Sosial, Kognisi, dan Bahhasa Anak Tuli terjemahan Andrian Hartotanojo. Yayasan Karya Bakti.

Marschark, M., Spencer, P. E., Adams, J., \& Sapere, P. (2011). Evidence-based practice in educating deaf and hard-of-hearing children: Teaching to their cognitive strengths and needs. European Journal of Special Needs Education, 26(1), 3-16. https://doi.org/10.1080/08856257.2011.543540. 
Moleong, L. (2008). Metodologi Penelitian Kuantitatif. PT. Raja Rosdakarya.

Muhadjir. (2000). Metode Penelitian Kualitatif. PT. Rake Serasin.

Mulyasa, E. (2005). Menjadi Guru Profesional, Menciptakan Pembelajaran Kreatif dan Menyenangkan. Rosda.

Noviandari, H., \& Huda, T. F. (2018). Peran sekolah dalam pendidikan anak berkebutuhan khusus di SDLB PGRI Bangorejo Banyuwangi. Jurnal Psikologi: Jurnal Ilmiah Fakultas Psikologi Universitas Yudharta Pasuruan, 5(1), 29-37. https://jurnal.yudharta.ac.id/v2/index.php/ILMUPSIKOLOGI/article/view/1168.

OECD. (2010). Educating Teachers for Diversity: Meeting the Challenge. In Educational Research and Innovation. OECD Publishing. https://doi.org/https://doi.org/10.1787/9789264079731-en.

Parey, B. (2019). Understanding teachers' attitudes towards the inclusion of children with disabilities in inclusive schools using mixed methods: The case of Trinidad. Teaching and Teacher Education, 83, 199-211. https://doi.org/10.1016/j.tate.2019.04.007.

Reed, \& M. (1984). Educating Hearing Impaired Kurikulum Children. Pen Univversity Perss.

Reyes Torres, A., Pich Ponce, E., \& García Pastor, M. D. (2012). Digital Storytelling as a Pedagogical Tool within a Didactic Sequence in Foreign Language Teaching El relato digital como herramienta pedagógica en la enseñanza de lenguas extranjeras a través del uso de la secuencia didáctica. Digital Education Review, 22, 1-18. https://roderic.uv.es/handle/10550/34827.

Sorkin, D. L., \& Zwolan, T. A. (2004). Trends in educational services for children with cochlear implants. International Congress Series, 1273(C), 417-421. https://doi.org/10.1016/j.ics.2004.08.066.

Sosu, E. M., Mtika, P., \& Colucci-Gray, L. (2010). Does initial teacher education make a difference? the impact of teacher preparation on student teachers' attitudes towards educational inclusion. Journal of Education for Teaching, 36(4), 389-405. https://doi.org/10.1080/02607476.2010.513847.

Suchyadi, Y., \& . N. (2018). Relationship between Principal Supervision in Increasing the Job Satisfaction of Private Junior High School Teachers in East Bogor District. Jhss (Journal of Humanities and Social Studies), 2(1), 26-29. https://doi.org/10.33751/jhss.v2i1.818.

Swanwick, R. (2010). Policy and practice in sign bilingual education: Development, challenges and directions. International Journal of Bilingual Education and Bilingualism, 13(2), 147-158. https://doi.org/10.1080/13670050903474069.

Taruvinga Mushoriwa. (2001). A study of the attitudes of primary school teachers in Harare towards the inclusion of blind children in regular classes. British Journal of Special Education, 28(3), 142-147. https://doi.org/10.1111/1467-8527.00214.

UNESCO. (1994). The Salamanca Statement And Framework For Action On Special Needs Education. United Nations Educational, Scientific and Cultural Organization.

Venail, F., Vieu, A., Artieres, F., Mondain, M., \& Uziel, A. (2010). Educational and employment achievements in prelingually deaf children who receive cochlear implants. Archives of Otolaryngology - Head and Neck Surgery, 136(4), 366-372. https://doi.org/10.1001/archoto.2010.31.

Vermandel, A., Weyler, J., De Wachter, S., \& Wyndaele, J. J. (2008). Toilet training of healthy young toddlers: A randomized trial between a daytime wetting alarm and timed potty training. Journal of

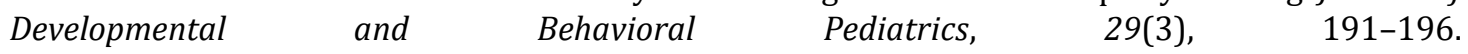
https://doi.org/10.1097/DBP.0b013e31816c433a.

Zaidman-Zait, A. (2007). Parenting a child with a cochlear implant: A critical incident study. Journal of Deaf Studies and Deaf Education, 12(2), 221-241. https://doi.org/10.1093/deafed/enl032. 